\title{
New Insulation Fiberboards from Sunflower Cake With Improved Thermal and Mechanical Properties
}

\author{
Philippe Evon (Corresponding author) \\ Université de Toulouse, INP, INRA \\ Laboratoire de Chimie Agro-industrielle, ENSIACET \\ 4 Allée Emile Monso, BP 44362, 31030 Toulouse Cedex 4, France \\ Tel: + 33 (0)5 $34323500 \quad$ E-mail: Philippe.Evon@ensiacet.fr \\ Justine Vinet \\ Université de Toulouse, INP, INRA \\ Laboratoire de Chimie Agro-industrielle, ENSIACET \\ 4 Allée Emile Monso, BP 44362, 31030 Toulouse Cedex 4, France \\ Tel: + 33 (0)5 $34323500 \quad$ E-mail: j.vinet2103@laposte.net
}

\author{
Matthieu Rigal
}

Université de Toulouse, INP, INRA

Laboratoire de Chimie Agro-industrielle, ENSIACET

4 Allée Emile Monso, BP 44362, 31030 Toulouse Cedex 4, France

Tel: + 33 (0)5 $34323500 \quad$ E-mail: Matthieu.Rigal@ensiacet.fr

\section{Laurent Labonne}

Université de Toulouse, INP, INRA

Laboratoire de Chimie Agro-industrielle, ENSIACET

4 Allée Emile Monso, BP 44362, 31030 Toulouse Cedex 4, France

Tel: + 33 (0)5 $34323500 \quad$ E-mail: Laurent.Labonne@ensiacet.fr

Virginie Vandenbossche 
Université de Toulouse, INP, INRA

Laboratoire de Chimie Agro-industrielle, ENSIACET

4 Allée Emile Monso, BP 44362, 31030 Toulouse Cedex 4, France

Tel: + 33 (0)5 $34323500 \quad$ E-mail: Virginie.Vandenbossche@ensiacet.fr

\author{
Luc Rigal
}

Université de Toulouse, INP, INRA

Laboratoire de Chimie Agro-industrielle, ENSIACET

4 Allée Emile Monso, BP 44362, 31030 Toulouse Cedex 4, France

Tel: + 33 (0)5 $34323500 \quad$ E-mail: Luc.Rigal@ensiacet.fr

Received: June 2, 2015

doi:10.5296/jas.v3i2.7738
Accepted: June 22, 2015.

URL: http://dx.doi.org/10.5296/ jas.v3i2.7738

\begin{abstract}
New thermal insulation fiberboards were manufactured by compression molding from a cake generated during the sunflower biorefinery. Fiberboards were cohesive mixtures of a natural binder and lignocellulosic fibers from sunflower cake. The natural binder ensured the board cohesion, and fibers acted as reinforcing fillers. The influence of molding conditions, i.e. binder type and binder content, on board density, mechanical and heat insulation properties was examined. The medium-density board containing $20 \%$ starch-based binder was a good compromise between mechanical and heat insulation properties $(78 \mathrm{~mW} / \mathrm{m} \mathrm{K}$ thermal conductivity). It could be positioned on walls and ceilings for thermal insulation of buildings.
\end{abstract}

Keywords: Sunflower, twin-screw extruder, lignocellulosic fibers, natural binder, compression molding, fiberboards, thermal insulation

\title{
1. Introduction
}

Twin-screw extrusion technology is an original and powerful solution for the biorefinery of sunflower (Helianthus annuus L.) whole plant. The latter is conducted in the presence of water, allowing the aqueous extraction of sunflower oil (Evon et al., 2010a). A filtration section along the barrel allows an extract (filtrate) and a raffinate (cake) to be collected separately, and oil extraction yield attains 57\%, under optimal operating conditions, with $14.3 \%$ residual cake dry matter oil content. Proteins and also pectins and hemicelluloses are co-extracted using the above conditions, thus protein extraction yield is $44 \%$, and cake residual protein content is $7.3 \%$ of the dry matter. 
To simplify conservation, cake is first dried because it has a relatively high moisture content of at least $62 \%$. Structurally, it is porous with a majority of lignocellulosic fibers (around 58\% of the dry matter), although there is also cell debris from breakdown of the kernels. The soluble molecules (proteins, pectins...) and lipids have been partly removed, whereas the structural plant molecules have not been extracted. Because the cake is a mixture of proteins and lignocellulosic fibers, it has been the subject of new valorizations. It can be thought of as a natural composite meaning that it can be processed by thermo-pressing into natural, cohesive, and value-added fiberboards, with the proteins acting as internal binder, and lignocellulosic fibers as reinforcing fillers (Evon et al., 2010a, 2010b, 2012a, 2012b, 2012c, 2015).

Temperature, pressure and length of time of thermo-pressing all increase fiberboard bending mechanical properties (Evon et al., 2010b, 2012b), and the highest flexural strength at break $(11.5 \mathrm{MPa})$ and highest elastic modulus $(2.2 \mathrm{GPa})$ are obtained with a cake having a dry matter residual oil content of $14.5 \%$, using the following molding conditions: $500 \mathrm{mg} / \mathrm{cm}^{2}$ cake quantity, $200{ }^{\circ} \mathrm{C}$ temperature for the two heated hydraulic press aluminum plates, 31.4 MPa pressure applied, and $60 \mathrm{~s}$ molding time (Evon et al., 2010b). Fiberboard thickness is just $3.9 \mathrm{~mm}$ with quite a high density $\left(1035 \mathrm{~kg} / \mathrm{m}^{3}\right)$. A fiberboard with these flexural properties, could be used in the handling and storage industry as pallet inter layer sheeting, or for furniture manufacture and natural, multi-board containers, e.g. composters, vegetable gardening crates.

Another industrial application of fiberboards made from renewable resources is heat insulation of buildings (walls and ceilings), where the main advantages of vegetable fibers are abundance, low cost (the majority are agricultural residues), minimal environmental impact, independence from fossil resources, and their natural capacity for thermal insulation (Saiah et al., 2010). Insulation boards can be made from maize husks and cobs (Sampathrajan et al;, 1992; Pinto et al., 2011; Paiva et al., 2012), a mixture of durian peels and coconut coir fibers (Khedari et al., 2003, 2004), cellulose (Nicolajsen, 2005), wastes from tissue paper manufacturing and corn peel (Lertsutthiwong et al.; 2008), kenaf fibers (Ardente et al., 2008), flax and hemp fibers (Kymäläinen \& Sjöberg, 2008; Korjenic et al., 2011; Benfratello et al., 2013), cotton stalk fibers (Zhou et al., 2010), jute fibers (Korjenic et al., 2011), coconut fibers (Panyakaew \& Fotios, 2011; Alavez-Ramirez et al., 2012), sunflower pith (Vandenbossche et al., 2012), date palm fibers (Chikhi et al., 2013), etc.

The thermal conductivity of insulation boards is often influenced by their densities (Khedari et al., 2003, 2004; Lertsutthiwong et al.; 2008; Zhou et al., 2010; Panyakaew \& Fotios, 2011; Vandenbossche et al., 2012; Benfratello et al., 2013; Chikhi et al., 2013), and low-density materials have the lowest thermal conductivities. As an example, the thermal conductivity of an insulation board from sunflower pith is only $38.5 \mathrm{~mW} / \mathrm{m} \mathrm{K}$ at $25{ }^{\circ} \mathrm{C}$ with a board density of $36 \mathrm{~kg} / \mathrm{m}^{3}$ (Vandenbossche et al., 2012). It is comparable to that of conventional insulation materials like expanded polystyrene $\left(37.4 \mathrm{~mW} / \mathrm{m} \mathrm{K}\right.$ with a board density of $\left.50 \mathrm{~kg} / \mathrm{m}^{3}\right)$, rock wool $\left(35.6 \mathrm{~mW} / \mathrm{m} \mathrm{K}\right.$ with a board density of $\left.115 \mathrm{~kg} / \mathrm{m}^{3}\right)$, and glass wool $(35.4 \mathrm{~mW} / \mathrm{m} \mathrm{K}$ with a board density of $26 \mathrm{~kg} / \mathrm{m}^{3}$ ). Thermal conductivity is higher with medium-density materials: $46-68 \mathrm{~mW} / \mathrm{m} \mathrm{K}$ at room temperature for coconut husk insulation boards with board densities 
of $250-350 \mathrm{~kg} / \mathrm{m}^{3}$ (Panyakaew \& Fotios, 2011), $81.5 \mathrm{~mW} / \mathrm{m} \mathrm{K}$ for a cotton stalk fibers insulation board with a board density of $450 \mathrm{~kg} / \mathrm{m}^{3}$ (Zhou et al., 2010), 89.9-107.9 mW/m K for hemp fibers insulation boards with board densities of $369-475 \mathrm{~kg} / \mathrm{m}^{3}$ (Benfratello et al., 2013), $103.6 \mathrm{~mW} / \mathrm{m} \mathrm{K}$ for a coconut coir insulation board with a board density of $540 \mathrm{~kg} / \mathrm{m}^{3}$ (Khedari et al., 2003), and $150 \mathrm{~mW} / \mathrm{m} \mathrm{K}$ for a date palm fibers insulation board with a board density of $754 \mathrm{~kg} / \mathrm{m}^{3}$ (Chikhi et al., 2013). Nevertheless, such boards are viable options for use in building insulation (walls and ceilings).

Heat insulation properties, of self-bonded fiberboards from cake generated during the biorefinery of sunflower whole plant in a twin-screw extruder are also promising, even if the corresponding board densities are quite high (904-966 kg/m ${ }^{3}$ ) (Evon et al., 2012c). Indeed, thermal conductivity at $25{ }^{\circ} \mathrm{C}$ is rather low for the three fiberboards tested, decreasing from 135.7 to $103.5 \mathrm{~mW} / \mathrm{m} \mathrm{K}$ as the board density decreased.

Furthermore, self-bonded fiberboards from such a cake with lower density $\left(500-858 \mathrm{~kg} / \mathrm{m}^{3}\right)$ and higher thickness (from 13.0 to $20.2 \mathrm{~mm}$ ) reveal a significant improvement in their heat insulation properties (Evon et al., 2014). Molding conditions, including mold temperature $\left(140-200{ }^{\circ} \mathrm{C}\right)$, pressure applied (14.7-24.5 MPa) and molding time (40-76 s), greatly affect board density and thus the mechanical and heat insulation properties. And, all fiberboards produced from these conditions are cohesive, proteins and lignocellulosic fibers still acting respectively as binder and reinforcing fillers. Board density increases with increasingly extreme molding conditions, rising from 500 to $858 \mathrm{~kg} / \mathrm{m}^{3}$. The mechanical properties increase at the same time (from 52 to $660 \mathrm{kPa}$ for flexural strength at break, from 5.9 to 49.4 MPa for elastic modulus, from 0.5 to $7.7 \mathrm{~kJ} / \mathrm{m}^{2}$ for Charpy impact strength, and from 19.2 to $47.1^{\circ}$ for Shore D surface hardness). Conversely, heat insulation properties improve with decreasing board density, and the lowest thermal conductivity $\left(88.5 \mathrm{~mW} / \mathrm{m} \mathrm{K}\right.$ at $\left.25{ }^{\circ} \mathrm{C}\right)$ is obtained with the least dense fiberboard, produced with a $140{ }^{\circ} \mathrm{C}$ mold temperature, a 14.7 MPa pressure applied and a $40 \mathrm{~s}$ molding time.

A medium mold temperature $\left(160{ }^{\circ} \mathrm{C}\right)$ is needed to obtain a good compromise between mechanical properties (272 $\mathrm{kPa}$ for flexural strength at break, 26.3 MPa for elastic modulus, $3.2 \mathrm{~kJ} / \mathrm{m}^{2}$ for Charpy impact strength, and $37.3^{\circ}$ for Shore D surface hardness), and heat insulation properties $(99.5 \mathrm{~mW} / \mathrm{m} \mathrm{K}$ for thermal conductivity) (Evon et al., 2014). The corresponding board density is medium $\left(687 \mathrm{~kg} / \mathrm{m}^{3}\right)$. And, because of its promising heat insulation properties, it could be positioned on walls and ceilings for thermal insulation of buildings. However, its insulation ability should be further improved.

A solution to improve significantly heat insulation properties of these fiberboards could be the use of natural binders, first solubilized in water and then mixed to the sunflower cake before compression molding plus drying. These external binders are with physical curing, the adhesion being achieved when water has evaporated. It then results in the appearance of bonds, usually of hydrogen type, between the biopolymer in the glue and the molecules (proteins, cellulose, hemicelluloses, etc.) contained in the materials to be joined. When used, natural binders favor both good cohesion and low density for the composite material, thus improving its thermal insulation ability. As an example, it is possible to manufacture 
insulating bio-based composites according to this technique, from sunflower stalks particles and chitosan (Mati-Baouche et al., 2014). And, the size grading of particles, the ratio chitosan/sunflower particles and the stress of compaction influence the thermal and mechanical properties of these new materials. Composites with a thermal conductivity of only $56 \mathrm{~mW} / \mathrm{m} \mathrm{K}$ and a maximum stress of $2 \mathrm{MPa}$ are obtained with a ratio of chitosan of $4.3 \%(\mathrm{w} / \mathrm{w})$ and a size grading of particles higher to $3 \mathrm{~mm}$. These thermal and mechanical performances are competitive with those of other insulating bio-based materials available on the market.

This study aimed to manufacture by compression molding at ambient temperature plus drying, new thermal insulation fiberboards with improved thermal and mechanical properties, from a mixture of an external binder in water solution and cake generated during the biorefinery of sunflower whole plant in a twin-screw extruder, and to evaluate the influence of molding conditions (binder type, and binder content) on their density, mechanical (flexural properties, and Shore D surface hardness) and heat insulation properties.

\section{Materials and methods}

\subsection{Raw material}

Twin-screw extruder thermo-mechanical fractionation was applied to a batch of oleic type sunflower (Helianthus annuus L.) whole plant (La Toulousaine de Céréales, France) (Table 1), harvested at plant maturity in September, pre-dried in a ventilated oven $\left(50{ }^{\circ} \mathrm{C}, 48 \mathrm{~h}\right)$ and then crushed with a hammer mill (Electra VS 1, France) through a $15 \mathrm{~mm}$ screen. Powdered plant moisture content (batch of $250 \mathrm{~kg}$ ) was 7.2 $\pm 0.0 \%$ (French standard NF V 03-903).

\subsection{Analytical methods}

The moisture contents were determined according to French standard NF V 03-903. The mineral contents were determined according to French standard NF V 03-322. The oil contents were determined according to French standard NF V 03-908. The protein contents were determined according to French standard NF V 18-100. The three parietal constituents (cellulose, hemicelluloses, and lignins) were estimated using the ADF-NDF method of Van Soest \& Wine (1967, 1968). Similarly, the water-soluble components were estimated by measuring the mass loss of the test sample after $1 \mathrm{~h}$ in boiling water. All determinations were carried out in duplicate.

Table 1. Chemical composition of the sunflower whole plant used for the experiment and of the cake obtained, after its thermo-mechanical fractionation in the Clextral BC 45 twin-screw extruder (\% of the dry matter).

\begin{tabular}{|l|c|c|}
\hline Material & Sunflower whole plant & Cake \\
\hline Minerals & $8.01 \pm 0.04$ & $7.07 \pm 0.04$ \\
\hline Lipids & $24.11 \pm 0.04$ & $17.40 \pm 0.13$ \\
\hline Proteins & $11.46 \pm 0.20$ & $9.01 \pm 0.33$ \\
\hline Cellulose & $24.81 \pm 0.59$ & $30.84 \pm 2.92$ \\
\hline Hemicelluloses & $8.10 \pm 0.30$ & $5.36 \pm 0.26$ \\
\hline
\end{tabular}




\begin{tabular}{|l|l|l|}
\hline Lignins & $10.27 \pm 0.16$ & $15.43 \pm 2.51$ \\
\hline Water-soluble components & $18.55 \pm 0.40$ & $12.39 \pm 0.12$ \\
\hline
\end{tabular}

\subsection{Particle size distribution}

A $500 \mathrm{~g}$ test sample mass of sunflower cake was treated in a Retsch AS 300 (Germany) vibratory sieve shaker to determine particle size distribution. Sieve acceleration was $1.5 \times g$, and sieving time $10 \mathrm{~min}$. For the tapped density of the cake, the measurement used a Granuloshop Densitap ETD-20 (France) volumenometer, and the corresponding apparent density, i.e. before compaction, was determined at the same time.

\subsection{Natural binders}

Three different natural binders were used in this study. All three have been chosen because of their commercial availability. The first one (S) was a starch-based binder supplied by Bostik (France) with the reference number 28474 , and usually used as a glue for wallpapers. Its starch content was $85 \%$. The second one (C) was a wood glue made of $96.6 \%$ casein, and supplied by Ipharos (France) under the name COLLASEUM Caseo Bois. The third and last one (G) was a bone glue made of gelatin (purity of about 90\%), supplied by Briançon Production (France), and usually used in crafts, i.e. restoration of antique furniture, marquetry, etc.

\subsection{Manufacturing of natural composites}

The three natural binders were first solubilized at room temperature $\left(20^{\circ} \mathrm{C}\right)$ for $10 \mathrm{~min}$ under stirring at concentrations of $5.6,8.8,12.5$, and $16.7 \%(\mathrm{w} / \mathrm{v})$ in $500 \mathrm{~mL}$ distilled water, respectively. Binder solutions were then mixed manually for $5 \mathrm{~min}$ with $250 \mathrm{~g}$ cake, corresponding to binder contents (w/w) of $10,15,20$, and $25 \%$, respectively. The mixtures were molded at room temperature $\left(20^{\circ} \mathrm{C}\right)$ by compression inside an aluminium mold using a 5 ton capacity hydraulic press, producing $150 \mathrm{~mm} \times 150 \mathrm{~mm}$ fiberboards. Pressure applied and molding time were $87 \mathrm{kPa}$ and $30 \mathrm{~s}$, respectively. Two insulation fiberboards were manufactured for all the molding conditions tested, including binder type, and binder content (Table 2). They were dried at $80{ }^{\circ} \mathrm{C}$ using a France Etuves XL2520 (France) ventilated oven to eliminate water added for binder dissolution, and they were then equilibrated in a climatic chamber $\left(60 \% \mathrm{RH}, 25^{\circ} \mathrm{C}\right)$ for three weeks before any analyses. A first fiberboard was used to assess mechanical properties for bending, and a second one for measuring Shore D surface hardness and heat insulation properties.

Table 2. Molding conditions for the manufacture of the twelve fiberboards.

\begin{tabular}{|l|l|l|l|l|l|l|l|l|l|l|l|l|}
\hline Board & S1 & S2 & S3 & S4 & C1 & C2 & C3 & C4 & G1 & G2 & G3 & G4 \\
\hline Binder type & S & S & S & S & C & C & C & C & G & G & G & G \\
\hline Binder content $(\%)$ & 10 & 15 & 20 & 25 & 10 & 15 & 20 & 25 & 10 & 15 & 20 & 25 \\
\hline
\end{tabular}

\subsection{Mechanical properties for bending}

Measurement of the flexural properties of the test specimens according to French standard NF EN 310 was undertaken using an Instron 33R4204 (USA) universal testing machine fitted 
with a $500 \mathrm{~N}$ load cell. Properties covered energy-to-break (E), breaking load (F), flexural strength at break $\left(\sigma_{\mathrm{f}}\right)$, and elastic modulus $\left(\mathrm{E}_{\mathrm{f}}\right)$. An estimation of the energy-to-break for each specimen, using the area under the load deformation curve from zero to rupture, was calculated using the trapezium method. Fiberboard was equilibrated for three weeks in a climatic chamber $\left(60 \% \mathrm{RH}, 25^{\circ} \mathrm{C}\right)$, and then $30 \mathrm{~mm}$ wide test specimens were cut and their thickness measured at three points and their length at two points, with a $0.01 \mathrm{~mm}$ resolution electronic digital sliding caliper. Thickness mean values (t) and length (l) were recorded to calculate the specimen volume, and they were all weighed to calculate mean apparent density (d). Test speed was $2 \mathrm{~mm} / \mathrm{min}$ with $100 \mathrm{~mm}$ grip separation. All determinations were carried out four times.

\subsection{Shore D surface hardness}

Shore D surface hardness of the fiberboards was assessed using a Bareiss (Germany) durometer according to French standard NF EN ISO 868. All determinations were carried out 48 times (24 times for each side of the fiberboard).

\subsection{Heat insulation properties}

Thermal conductivity $(\lambda)$ and thermal resistance $(\mathrm{R})$ of fiberboards were determined at three temperatures $\left(10{ }^{\circ} \mathrm{C}, 25{ }^{\circ} \mathrm{C}\right.$, and $40{ }^{\circ} \mathrm{C}$ ) according to the ISO 8302 08-91 standard, using a Lambda-Meßtechnik GmbH Dresden EP 500 (Germany) $\lambda$-Meter hot plate apparatus. The area measured was $150 \mathrm{~mm} \times 150 \mathrm{~mm}$, and because of swelling in the climatic chamber, fiberboards had to be cut before measuring to obtain the required dimensions. The difference of temperature between the two plates was $5 \mathrm{~K}$. Measurements were also made with the bulk cake using a polycarbonate box $1 \mathrm{~mm}$ thick and $50 \mathrm{~mm}$ high. Here, the solid, cake particles were evenly distributed in the box, and a 'box effect' correction made on the thermal conductivity measurements. The cake was equilibrated in a climatic chamber $(60 \% \mathrm{RH}$, $25^{\circ} \mathrm{C}$ ) for three weeks before being tested. Both determinations were carried out once.

\subsection{Statistical analyses}

Determinations were conducted two times for board moisture content, four times for flexural properties and 48 times for Shore D surface hardness, and data are expressed as means \pm standard deviations. The means were compared by the use of a single-factor analysis of variance (ANOVA) using the GLM procedure of the SAS data analysis software. The comparison between the different individual means was performed using the Duncan's multiple range test at a $5 \%$ probability level.

\section{Results and discussion}

\subsection{Cake production by twin-screw extrusion}

A Clextral (France) BC 45 twin-screw extruder was used to conduct simultaneously at $80{ }^{\circ} \mathrm{C}$ the thermo-mechanical fractionation of whole plant and the aqueous extraction of sunflower oil, and the screw configuration was the same as that previously optimized (Evon et al., 2010a). A filtrate was collected continuously from the filter section, and a cake was generated at the same time. Lipids and water-soluble components, mostly proteins but also pectins and 
hemicelluloses, were partly extracted during this process. Operating conditions used for cake production were $62.5 \mathrm{rpm}$ for the screw rotation speed, $5.7 \mathrm{~kg} / \mathrm{h}$ for the inlet flow rate of the sunflower whole plant, and $20.2 \mathrm{~kg} / \mathrm{h}$ for the inlet flow rate of the water. The flow rate of the cake was $12.1 \mathrm{~kg} / \mathrm{h}$, and its moisture content was $67.8 \pm 0.2 \%$. Immediately after production of this cake, and to facilitate conservation, it was dried in a ventilated oven, and the powder produced consisted of inhomogeneous particles (Figure 1 and Figure 2), whose chemical composition is shown in Table 1 . It revealed an oil content (17.4\% of the dry matter) quite comparable to that of a cake used in a previous study for the manufacture of self-bonded insulating fiberboards (17.6\%) (Evon et al., 2014), leading to an oil extraction yield, based on the residual oil content in the cake, of $46.4 \pm 0.4 \%$. The corresponding protein extraction yield, based on the residual protein content in the cake, was $41.6 \pm 2.1 \%$.

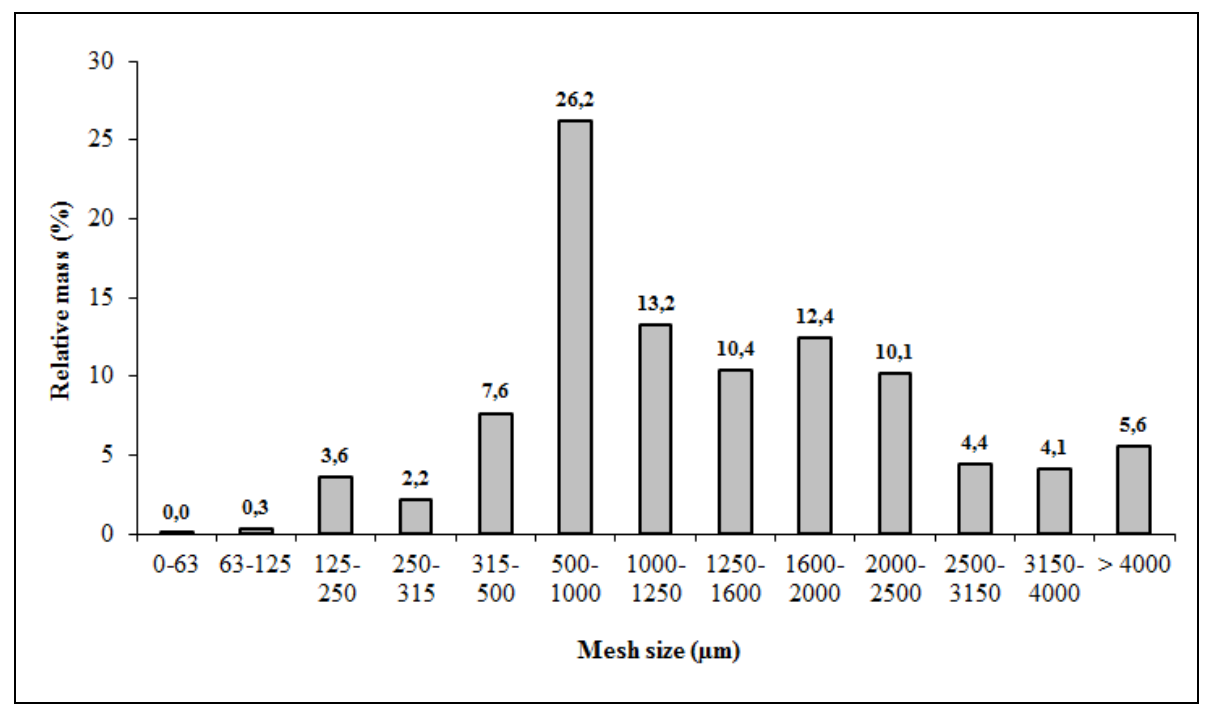

Figure 1. Particle size distribution in the cake.

Due to the fact that some lipids and proteins were partly extracted by water during the process, this meant that their residual contents in the cake decreased compared to initial whole plant values: from 24.1 to $17.4 \%$ of the dry matter, and from 11.5 to $9.0 \%$ of the dry matter, respectively (Table 1). Similarly, with hemicelluloses and water-soluble components, the same tendency was also observed: from 8.1 to $5.4 \%$ of the dry matter, and from 18.6 to $12.4 \%$ of the dry matter, respectively. On the other hand, cellulose and lignins were not extracted, because both these biopolymers are insoluble in water. Thus, in parallel, a significant increase relative to their initial values was observed: from 24.8 to $30.8 \%$ of the dry matter, and from 10.3 to $15.4 \%$ of the dry matter, respectively.

The particle size distribution inside the cake (Figure 1) revealed the presence of large particles (above $1 \mathrm{~mm}$ ), mainly composed of lignocellulosic fibers originating essentially from the sunflower stalk and head, smaller particles (diameter between 500 and $1000 \mu \mathrm{m}$ ), and also fines (diameter inferior to $500 \mu \mathrm{m}$ ). The two last populations contained not only smaller fibers but also spherical particles, from the kernel breakdown process. And, it has to be mentioned that such continuity in particle sizes classically leads to good mechanical properties for composite materials. Apparent and tapped densities of the cake were also 


\section{MInstitute Macrothink $_{\text {Int }}$}

Journal of Agricultural Studies

ISSN 2166-0379

2015, Vol. 3, No. 2

measured, and they were $214.5 \pm 2.7$ and $233.3 \pm 1.3 \mathrm{~kg} / \mathrm{m}^{3}$, respectively. In conclusion, it was reasonable to suppose that lignocellulosic fibers would act as effective reinforcing fillers inside thermal insulation fiberboards. Moreover, because the cake oil content was higher than in previous studies (Evon et al., 2010a, 2010b), residual oil in fiberboards would contribute to make them less water-sensitive and also more durable than truly deoiled agromaterials, in spite of their overall hydrophilic character.

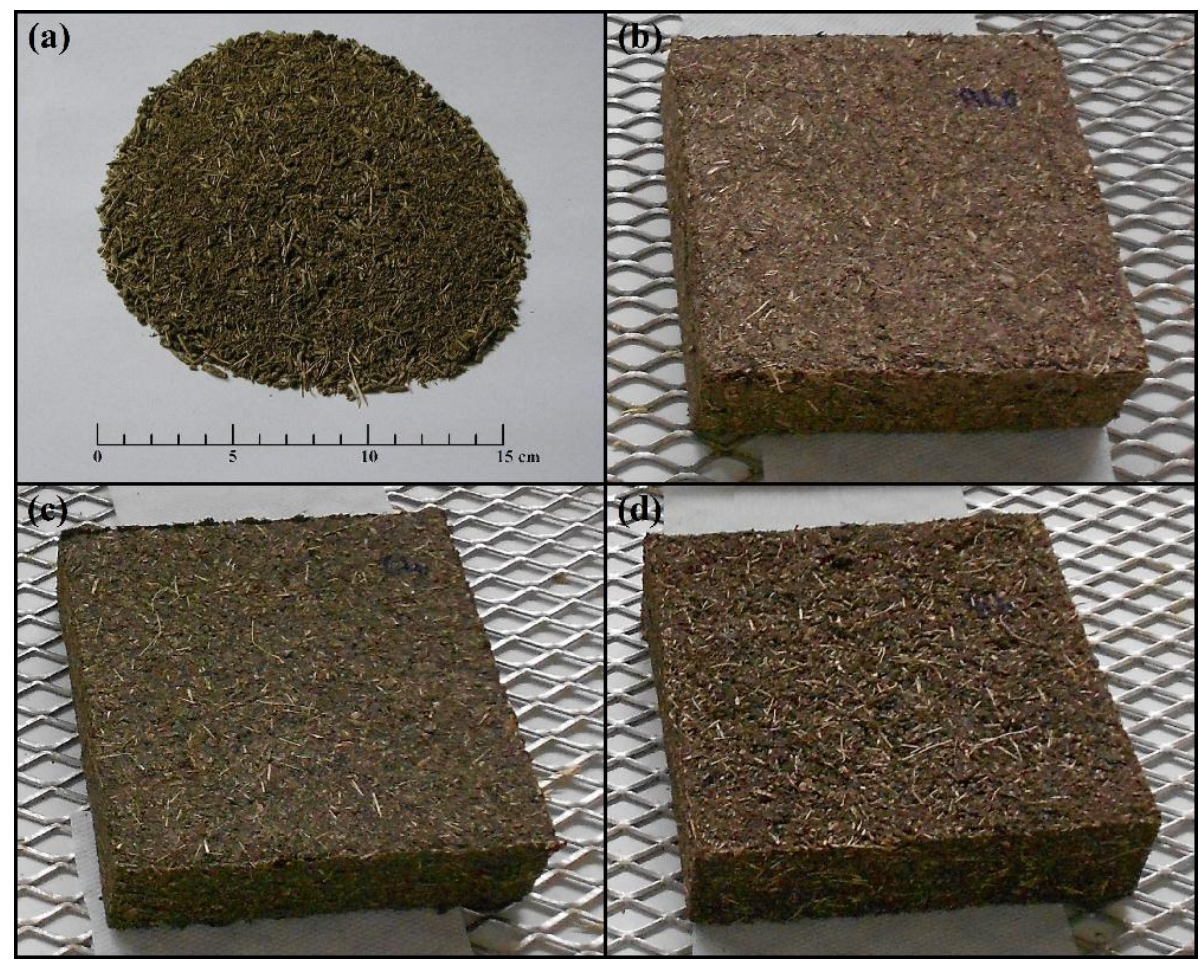

Figure 2. Photographs of the cake (a) and of the three fiberboards with $25 \%$ binder content (b, board S4; c, board C4; d, board G4).

\subsection{Influence of molding conditions on mechanical properties of fiberboards}

Twelve fiberboards were manufactured using different molding conditions (Table 2 and photographs in Figure 2). Conditions included binder type, and binder content. The three different natural binders tested were a starch-based binder $(\mathrm{S})$, casein $(\mathrm{C})$, and gelatin $(\mathrm{G})$. The binder content, in particular, varied from 10 to $25 \%$ (w/w). Compression molding was conducted at room temperature $\left(20{ }^{\circ} \mathrm{C}\right)$, and the pressure applied was only $87 \mathrm{kPa}$. It was significantly lower than for other studies producing self-bonded fiberboards from sunflower cake: from 14.7 to $24.5 \mathrm{MPa}$ (Evon et al., 2014), up to 31.4 MPa (Evon et al., 2010b), from 31.4 to $35.3 \mathrm{MPa}$ (Evon et al., 2012c), and from 24.5 to 49.0 MPa (Evon et al., 2012b). The objective for such a choice was to minimize the density of the materials obtained, in order to manufacture fiberboards with medium-density (from 250 to $450 \mathrm{~kg} / \mathrm{m}^{3}$ ). Molding time was only $30 \mathrm{~s}$, which was quite similar to values used in two previous studies (30 s and $40 \mathrm{~s}$ ) (Evon et al., 2010b, 2014). Cake quantity for all the experiments was $1111 \mathrm{mg} / \mathrm{cm}^{2}$, and this led to the manufacture of thicker fiberboards compared with other materials from sunflower cake described in previous studies (Evon et al., 2010b, 2012b, 2012c, 2014): at least $34.8 \mathrm{~mm}$ 
(and up to $40.6 \mathrm{~mm}$ ) after climatic chamber conditioning $\left(60 \% \mathrm{RH}, 25{ }^{\circ} \mathrm{C}\right.$ ) for three weeks (Table 3).

Table 3. Mechanical properties of the twelve fiberboards manufactured by compression molding.

\begin{tabular}{|c|c|c|c|c|c|c|}
\hline Board & S1 & S2 & S3 & S4 & $\mathrm{C} 1$ & $\mathrm{C} 2$ \\
\hline \multicolumn{7}{|c|}{ Drying at $80^{\circ} \mathrm{C}$} \\
\hline Term $(\mathrm{h})$ & 36.0 & 39.5 & 46.0 & 51.4 & 24.3 & 33.5 \\
\hline \multicolumn{7}{|c|}{ Flexural properties } \\
\hline $\mathrm{H}_{\mathrm{FB}}(\%)^{1}$ & $8.0 \pm 0.0^{\mathrm{ef}}$ & $8.3 \pm 0.1^{\text {cde }}$ & $8.6 \pm 0.2^{\mathrm{abc}}$ & $9.0 \pm 0.0^{\mathrm{a}}$ & $8.3 \pm 0.2^{\mathrm{de}}$ & $8.0 \pm 0.0^{\mathrm{ef}}$ \\
\hline $\mathrm{t}(\mathrm{mm})$ & $34.8 \pm 0.5^{\mathrm{f}}$ & $37.1 \pm 0.6^{\mathrm{d}}$ & $38.7 \pm 0.7^{\mathrm{c}}$ & $40.6 \pm 1.2^{\mathrm{a}}$ & $38.3 \pm 0.8^{\mathrm{c}}$ & $37.3 \pm 0.5^{\mathrm{d}}$ \\
\hline $\mathrm{d}\left(\mathrm{kg} / \mathrm{m}^{3}\right)$ & $338.3 \pm 7.6^{\mathrm{e}}$ & $346.4 \pm 6.2^{\mathrm{e}}$ & $357.9 \pm 10.9^{\mathrm{d}}$ & $375.3 \pm 14.3^{\mathrm{c}}$ & $266.1 \pm 4.7^{\mathrm{h}}$ & $339.6 \pm 2.0^{\mathrm{e}}$ \\
\hline $\mathrm{E}(\mathrm{mJ})$ & $34.9 \pm 3.3^{\mathrm{fg}}$ & $67.4 \pm 5.3^{\mathrm{e}}$ & $127.3 \pm 9.9^{\mathrm{d}}$ & $326.1 \pm 37.0^{\mathrm{b}}$ & $8.3 \pm 0.7^{\mathrm{g}}$ & $50.6 \pm 6.0^{\mathrm{ef}}$ \\
\hline $\mathrm{F}(\mathrm{N})$ & $44.8 \pm 5.3^{\mathrm{f}}$ & $70.7 \pm 7.7^{\mathrm{e}}$ & $104.0 \pm 9.2^{\mathrm{d}}$ & $199.3 \pm 13.6^{c}$ & $8.9 \pm 0.7^{\mathrm{g}}$ & $49.0 \pm 4.0^{\mathrm{ef}}$ \\
\hline$\sigma_{\mathrm{f}}(\mathrm{kPa})$ & $184.6 \pm 21.7^{\mathrm{e}}$ & $256.9 \pm 27.9^{\mathrm{de}}$ & $347.0 \pm 30.7^{\mathrm{d}}$ & $604.4 \pm 41.3^{\mathrm{c}}$ & $30.4 \pm 4.5^{\mathrm{f}}$ & $176.3 \pm 14.4^{\mathrm{e}}$ \\
\hline $\mathrm{E}_{\mathrm{f}}(\mathrm{MPa})$ & $7.0 \pm 1.2^{\mathrm{e}}$ & $9.9 \pm 1.3^{\mathrm{d}}$ & $9.5 \pm 1.3^{\mathrm{d}}$ & $12.9 \pm 1.4^{\mathrm{c}}$ & $0.8 \pm 0.1^{\mathrm{f}}$ & $4.8 \pm 0.3^{\mathrm{e}}$ \\
\hline \multicolumn{7}{|c|}{ Surface hardness } \\
\hline Shore D $\left(^{\circ}\right)$ & $14.5 \pm 1.2^{\mathrm{gh}}$ & $15.5 \pm 1.3^{\mathrm{fg}}$ & $18.9 \pm 1.9^{\mathrm{cd}}$ & $24.6 \pm 3.3^{b}$ & $6.7 \pm 0.9^{i}$ & $13.0 \pm 1.4^{\mathrm{h}}$ \\
\hline
\end{tabular}

\begin{tabular}{|c|c|c|c|c|c|c|}
\hline Board & $\mathrm{C} 3$ & $\mathrm{C} 4$ & G1 & $\mathrm{G} 2$ & G3 & G4 \\
\hline \multicolumn{7}{|c|}{ Drying at $80^{\circ} \mathrm{C}$} \\
\hline Term (h) & 45.7 & 51.3 & 24.0 & 26.6 & 27.1 & 27.3 \\
\hline \multicolumn{7}{|c|}{ Flexural properties } \\
\hline $\mathrm{H}_{\mathrm{FB}}(\%)^{1}$ & $8.3 \pm 0.2^{\mathrm{de}}$ & $7.8 \pm 0.2^{\mathrm{f}}$ & $8.8 \pm 0.2^{\mathrm{ab}}$ & $9.0 \pm 0.5^{\mathrm{a}}$ & $8.8 \pm 0.2^{\mathrm{ab}}$ & $8.5 \pm 0.0^{\mathrm{bcc}}$ \\
\hline $\mathrm{t}(\mathrm{mm})$ & $35.8 \pm 1.0^{\mathrm{e}}$ & $35.5 \pm 0.9^{\mathrm{e}}$ & $37.2 \pm 0.6^{\mathrm{d}}$ & $38.5 \pm 0.6^{\mathrm{c}}$ & $39.9 \pm 0.6^{\mathrm{b}}$ & $39.6 \pm 0.3^{b}$ \\
\hline $\mathrm{d}\left(\mathrm{kg} / \mathrm{m}^{3}\right)$ & $394.5 \pm 10.9^{b}$ & $439.0 \pm 14.3^{\mathrm{a}}$ & $254.9 \pm 4.1^{\mathrm{i}}$ & $270.8 \pm 5.2^{\mathrm{h}}$ & $280.9 \pm 3.9^{\mathrm{g}}$ & $315.1 \pm 7.8^{\mathrm{f}}$ \\
\hline $\mathrm{E}(\mathrm{mJ})$ & $238.0 \pm 24.2^{\mathrm{c}}$ & $356.7 \pm 35.3^{\mathrm{a}}$ & $2.0 \pm 0.4^{\mathrm{g}}$ & $1.8 \pm 0.2^{\mathrm{g}}$ & $3.3 \pm 0.5^{\mathrm{g}}$ & $12.2 \pm 1.3^{\mathrm{g}}$ \\
\hline$F(N)$ & $252.5 \pm 23.9^{\mathrm{b}}$ & $372.0 \pm 35.7^{\mathrm{a}}$ & $2.8 \pm 0.3^{\mathrm{g}}$ & $3.0 \pm 0.4^{\mathrm{g}}$ & $4.8 \pm 0.8^{\mathrm{g}}$ & $17.6 \pm 1.4^{\mathrm{g}}$ \\
\hline$\sigma_{\mathrm{f}}(\mathrm{kPa})$ & $987.0 \pm 93.5^{\mathrm{b}}$ & $1477.7 \pm 141.7^{\mathrm{a}}$ & $10.2 \pm 0.9^{\mathrm{f}}$ & $10.2 \pm 1.4^{\mathrm{f}}$ & $14.9 \pm 2.5^{\mathrm{f}}$ & $55.9 \pm 4.6^{\mathrm{f}}$ \\
\hline $\mathrm{E}_{\mathrm{f}}(\mathrm{MPa})$ & $25.6 \pm 2.0^{\mathrm{b}}$ & $34.4 \pm 3.7^{\mathrm{a}}$ & $0.3 \pm 0.1^{\mathrm{f}}$ & $0.5 \pm 0.0^{\mathrm{f}}$ & $0.5 \pm 0.2^{\mathrm{f}}$ & $1.8 \pm 0.2^{\mathrm{f}}$ \\
\hline \multicolumn{7}{|c|}{ Surface hardness } \\
\hline Shore D $\left(^{\circ}\right)$ & $17.9 \pm 1.4^{\mathrm{de}}$ & $20.3 \pm 2.1^{\mathrm{c}}$ & $4.8 \pm 0.4^{\mathrm{j}}$ & $13.8 \pm 1.8^{\mathrm{gh}}$ & $16.8 \pm 1.8^{\mathrm{ef}}$ & $27.4 \pm 2.3^{\mathrm{a}}$ \\
\hline
\end{tabular}

${ }^{1} \mathrm{H}_{\mathrm{FB}}$ is the moisture content of the fiberboard (\%). Fiberboards were equilibrated in a climatic chamber $\left(60 \% \mathrm{RH}, 25^{\circ} \mathrm{C}\right)$ for three weeks before moisture measurements. Means in the same line with the same letter $(\mathrm{a}-\mathrm{j})$ are not significantly different at $P<0.05$.

No particular problem was observed for dissolution in distilled water of the three natural binders, including the highest concentration, i.e. $16.7 \%(\mathrm{w} / \mathrm{v})$. In the same way, manual mixing of binder solutions with cake plus compression molding did not reveal any difficulty for all the molding conditions tested. The twelve fiberboards manufactured were carefully removed from the aluminium mold immediately after compression molding. And, they were then dried at $80{ }^{\circ} \mathrm{C}$ using a ventilated oven to eliminate water added for binder dissolution, i.e. $500 \mathrm{~g}$. The drying duration depended on both binder type and binder content, varying from 24.0 to $51.4 \mathrm{~h}$ (Table 3). For starch-based binder and casein, it increased linearly with binder 
content: from 36.0 to $51.4 \mathrm{~h}$, and from 24.3 to $51.3 \mathrm{~h}$, respectively. In both cases, the increase in binder concentration in distilled water led to a significant increase in binder solution viscosity, and this contributed to slow more and more the water evaporation kinetics. Conversely, the gelatin solutions were all very fluid, including that corresponding to the highest concentration. And, this led to a slower increase in drying duration with the increase in gelatin content: from $24.0 \mathrm{~h}$ for board G1 to $27.3 \mathrm{~h}$ for board G4.

All fiberboards produced were cohesive mixtures of the natural binder and lignocellulosic fibers, in what could be considered as a natural composite. The natural binder contributed to ensure cohesion of the agromaterial, in addition to the entanglement of lignocellulosic fibers from sunflower cake also acting as reinforcement. Conditioning in the climatic chamber was conducted immediately after compression molding plus drying in order to assess the mechanical and heat insulation properties of fiberboards from equilibrated materials. And, moisture contents of equilibrated boards S1 to S4 increased progressively (from 8.0 to $9.0 \%$ ) with increasing starch-based binder content, due to the natural hydrophilic character of starch (Table 3). Conversely, moisture contents of equilibrated fiberboards made from casein and gelatin were quite independent on binder content, and they were between 7.8 and $8.3 \%$, and between 8.5 and $9.0 \%$, respectively. And, higher moisture contents for boards G1 to G4 could be explained by their lower densities, compared to the other boards (Table 3). Indeed, during climatic chamber conditioning of fiberboards, water uptake was a little higher for these boards, due to their higher porosity.

The density of the equilibrated fiberboards was greatly affected by the molding conditions used, increasing with increasing binder content (Table 3). For boards using gelatin as binder, it varied from 255 to $315 \mathrm{~kg} / \mathrm{m}^{3}$. And, gelatin was the natural binder producing the least dense boards of the entire study. With the starch-based binder, fiberboards obtained were denser. Indeed, board density was $338 \mathrm{~kg} / \mathrm{m}^{3}$ for the $10 \%$ binder content (board $\mathrm{S} 1$ ), and it reached $375 \mathrm{~kg} / \mathrm{m}^{3}$ for the $25 \%$ binder content (board S4). The increase in board density with increasing binder content was much more significant with casein, ranging from $266 \mathrm{~kg} / \mathrm{m}^{3}$ for board $\mathrm{C} 1$ to $439 \mathrm{~kg} / \mathrm{m}^{3}$ for board $\mathrm{C} 4$. And, even if fiberboards made with 10 and $15 \%$ casein (i.e. boards $\mathrm{C} 1$ and $\mathrm{C} 2$, respectively) were less dense than their equivalents made from the starch-based binder (i.e. boards S1 and S2, respectively), it was the opposite for the two highest binder contents tested, i.e. 20 and 25\%, respectively. Indeed, for the $20 \%$ binder content, density of board C3 was $394 \mathrm{~kg} / \mathrm{m}^{3}$ instead of $358 \mathrm{~kg} / \mathrm{m}^{3}$ for board S3. In the same way, for the $25 \%$ binder content, board density reached $439 \mathrm{~kg} / \mathrm{m}^{3}$ with casein (board C4), and it was only $375 \mathrm{~kg} / \mathrm{m}^{3}$ for board S4 that was made from the starch-based binder. And, board $\mathrm{C} 4$ was the densest fiberboard of the entire study.

The mechanical properties of fiberboards were also clearly influenced by the molding conditions, and could be correlated to their densities. Indeed, the higher the fiberboard density, the higher its mechanical properties (Table 3). Regarding flexural properties, the energy-to-break, the breaking load, the flexural strength at break and the elastic modulus increased progressively from 2.0 to $356.7 \mathrm{~mJ}$, from 2.8 to $372.0 \mathrm{~N}$, from 10.2 to $1477.7 \mathrm{kPa}$, and from 0.3 to $34.4 \mathrm{MPa}$, respectively, with increasing fiberboard density (Table 3 and Figure 3). Similarly, the Shore D surface hardness increased from 4.8 to $27.4^{\circ}$. Thus, the most 


\section{Macrothink}

fragile fiberboard was also the least dense board, and it was board G1. Conversely, the densest fiberboard (C4), was also the most mechanically resistant board of the entire study.

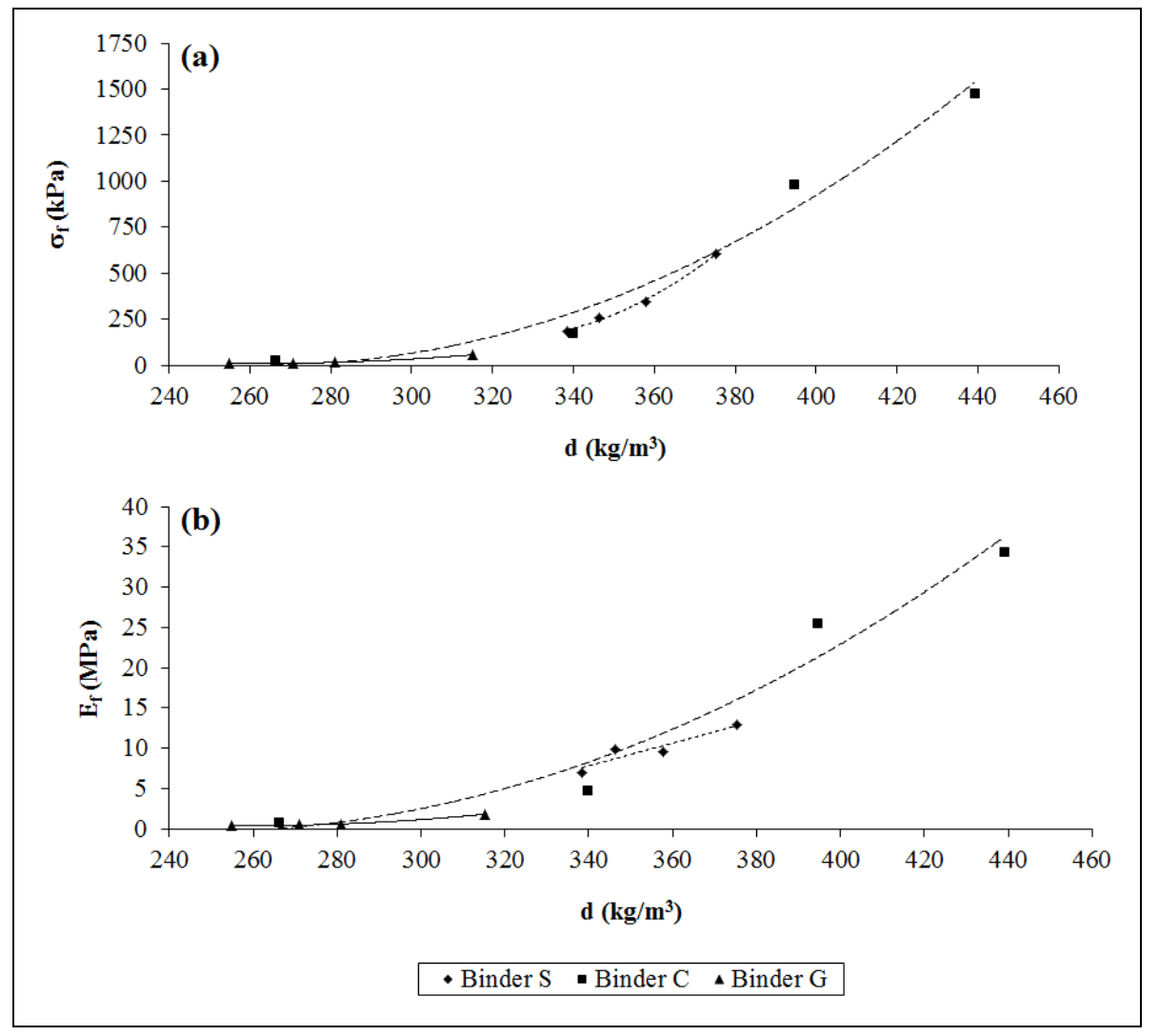

Figure 3. Flexural strength at break (a) and elastic modulus (b) of the twelve fiberboards manufactured by compression molding, as a function of their density.

In conclusion, an improvement in fiber wetting and binding efficiency was logically observed with the increase in binder content for the three natural binders tested, leading to an increase in flexural properties of fiberboards. However, gelatin revealed a very low binding ability, leading to boards G1 to G4 particularly fragile mechanically, including board G4 manufactured from the highest binder content, i.e. 25\%. This was probably due to the temperature sensitivity of gelatin during water evaporation (drying at $80{ }^{\circ} \mathrm{C}$ using a ventilated oven), leading to its partial thermal degradation. Conversely, the starch-based binder and casein led to much higher mechanical properties. And, if the starch-based binder led to more mechanically resistant fiberboards for the two lowest binder contents (i.e. 10 and 15\%), it was casein that generated the best mechanical properties for bending for the two highest binder contents (i.e. 20 and $25 \%$ ).

\subsection{Influence of molding conditions on heat insulation properties of fiberboards}

The heat insulation properties of the twelve fiberboards were measured at three temperatures: $10{ }^{\circ} \mathrm{C}, 25{ }^{\circ} \mathrm{C}$, and $40{ }^{\circ} \mathrm{C}$. As generally observed for thermal insulation solids, the thermal conductivity of the twelve fiberboards tested increased with increasing temperature, with the thermal resistance logically and simultaneously decreasing (Table 4). The same tendency was also observed for measurements made on the bulk cake. Consequently, the capacity for 


\section{Al Macrothink}

Journal of Agricultural Studies

ISSN 2166-0379

2015, Vol. 3, No. 2

thermal insulation of all the materials tested, decreased noticeably with increasing temperature. The thermal conductivity of the bulk cake and of the twelve fiberboards was also clearly influenced by their density, and it tended to increase with increasing density (Figure 4a). Similar characteristics have been observed on several occasions, in particular for insulation boards made from durian peel and coconut coir (Khedari et al., 2003, 2004), wastes from tissue paper manufacturing and corn peel (Lertsutthiwong et al., 2008), cotton stalk fibers (Zhou et al., 2010), coconut husk and bagasse (Panyakaew \& Fotios, 2011), sunflower pith (Vandenbossche et al., 2012), hemp fibers (Benfratello et al., 2013), date palm fibers (Chikhi et al., 2013), and sunflower cake from whole plant (Evon et al., 2014). At the same time, the thermal resistance logically decreased (Figure 4b), and these trends were observed at all three temperatures. However, here we will focus on the $25{ }^{\circ} \mathrm{C}$ results, considered as ambient temperature.

Table 4. Thermal conductivity $(\lambda)$ and thermal resistance $(\mathrm{R})$ at three temperatures $\left(10{ }^{\circ} \mathrm{C}\right.$, $25{ }^{\circ} \mathrm{C}$, and $40{ }^{\circ} \mathrm{C}$ ) of the bulk cake and of the twelve fiberboards manufactured by compression molding.

\begin{tabular}{|l|l|l|l|l|l|l|l|l|l|}
\hline Board & $\begin{array}{l}\text { Bulk } \\
\text { cake }\end{array}$ & S1 & S2 & S3 & S4 & C1 & C2 & C3 & C4 \\
\hline$\lambda(\mathrm{mW} / \mathrm{m} \mathrm{K})$ & \multicolumn{9}{|l|}{$\mid$} \\
\hline $10^{\circ} \mathrm{C}$ & 58.0 & 71.8 & 72.6 & 74.8 & 79.0 & 66.0 & 69.4 & 78.3 & 82.3 \\
\hline $25^{\circ} \mathrm{C}$ & 62.0 & 74.4 & 75.7 & 77.6 & 83.4 & 67.6 & 72.1 & 79.1 & 84.8 \\
\hline $40^{\circ} \mathrm{C}$ & 64.1 & 77.0 & 79.7 & 81.4 & 89.6 & 70.1 & 76.1 & 82.1 & 89.4 \\
\hline $\mathrm{R}\left(\mathrm{m}^{2} \mathrm{~K} / \mathrm{W}\right)$ & 0.897 & 0.485 & 0.511 & 0.517 & 0.514 & 0.581 & 0.537 & 0.457 & 0.431 \\
\hline $10^{\circ} \mathrm{C}$ & 0.839 & 0.468 & 0.490 & 0.499 & 0.487 & 0.567 & 0.517 & 0.452 & 0.418 \\
\hline $25^{\circ} \mathrm{C}$ & 0.812 & 0.452 & 0.466 & 0.476 & 0.453 & 0.547 & 0.489 & 0.436 & 0.397 \\
\hline $40^{\circ} \mathrm{C}$ &
\end{tabular}

\begin{tabular}{|l|l|l|l|l|}
\hline Board & G1 & G2 & G3 & G4 \\
\hline$\lambda(\mathrm{mW} / \mathrm{m} \mathrm{K})$ & 62.3 & 66.0 & 66.4 & 68.5 \\
\hline $10^{\circ} \mathrm{C}$ & 64.0 & 69.5 & 71.0 & 73.1 \\
\hline $25^{\circ} \mathrm{C}$ & 67.0 & 72.3 & 74.6 & 78.1 \\
\hline $40^{\circ} \mathrm{C}$ & 0.598 & 0.584 & 0.601 & 0.578 \\
\hline $\mathrm{R}\left(\mathrm{m}^{2} \mathrm{~K} / \mathrm{W}\right)$ & 0.582 & 0.554 & 0.562 & 0.542 \\
\hline $10^{\circ} \mathrm{C}$ & 0.556 & 0.532 & 0.535 & 0.507 \\
\hline $25^{\circ} \mathrm{C}$ &
\end{tabular}

Thermal conductivity was rather low for the twelve fiberboards (Table 4), due to their medium densities (from 255 to $439 \mathrm{~kg} / \mathrm{m}^{3}$ ) contributing to better heat insulation properties compared with previous results obtained with denser materials from sunflower cake, i.e. self-bonded fiberboards: from 64.0 to $84.8 \mathrm{~mW} / \mathrm{m} \mathrm{K}$ for thermal conductivity at $25{ }^{\circ} \mathrm{C}$ instead of $88.5-110.5 \mathrm{~mW} / \mathrm{m} \mathrm{K}$ with board density between 500 and $858 \mathrm{~kg} / \mathrm{m}^{3}$ (Evon et al., 2014), and 103.5-135.7 mW/m K with board density between 904 and $966 \mathrm{~kg} / \mathrm{m}^{3}$ (Evon et al., 
2012c). Moreover, as already mentioned, it decreased with the decrease in board density for each natural binder tested (Table 4 and Figure $4 \mathrm{a}$ ). It was $84.8 \mathrm{~mW} / \mathrm{m} \mathrm{K}$ for the most dense $\left(439 \mathrm{~kg} / \mathrm{m}^{3}\right)$ fiberboard of the entire study, i.e. board $\mathrm{C} 4$, and only $64.0 \mathrm{~mW} / \mathrm{m} \mathrm{K}$ for the least dense one $\left(255 \mathrm{~kg} / \mathrm{m}^{3}\right)$, i.e. board $\mathrm{G} 1$. The increase in porosity within the boards thus improved their thermal insulation capacity, and such values were in line with the thermal conductivities of other experimental medium-density insulation boards, made from coconut husk (Panyakaew \& Fotios, 2011), cotton stalk fibers (Zhou et al., 2010) or hemp fibers (Benfratello et al., 2013), and considered as viable options for use in building insulation: $46-68 \mathrm{~mW} / \mathrm{m} \mathrm{K}\left(250-350 \mathrm{~kg} / \mathrm{m}^{3}\right.$ for board densities), $81.5 \mathrm{~mW} / \mathrm{m} \mathrm{K}\left(450 \mathrm{~kg} / \mathrm{m}^{3}\right.$ for board density) and $89.9-107.9 \mathrm{~mW} / \mathrm{m} \mathrm{K}\left(369-475 \mathrm{~kg} / \mathrm{m}^{3}\right.$ for board densities), respectively. At the same time, the thermal resistance varied from 0.418 to $0.582 \mathrm{~m}^{2} \mathrm{~K} / \mathrm{W}$ (Table 4 and Figure 4b).

Because the heat insulation properties of the fiberboards improved with decreasing density (Figure 4), the fiberboard with the weakest thermal conductivity (board G1) also corresponded to the most fragile insulation board (Table 3). Conversely, the most conductive fiberboard (board C4) was also the most mechanically resistant insulation board. Consequently, the medium density $\left(358 \mathrm{~kg} / \mathrm{m}^{3}\right)$ fiberboard from trial $\mathrm{S} 3$, i.e. the board containing $20 \%$ starch-based binder, was a good compromise between mechanical properties (127 mJ for energy-to-break, $104 \mathrm{~N}$ for breaking load, $347 \mathrm{kPa}$ for flexural strength at break, 9.5 $\mathrm{MPa}$ for elastic modulus, and $18.9^{\circ}$ for Shore D surface hardness) and those for heat insulation $\left(77.6 \mathrm{~mW} / \mathrm{m} \mathrm{K}\right.$ for thermal conductivity at $25{ }^{\circ} \mathrm{C}$, and $0.499 \mathrm{~m}^{2} \mathrm{~K} / \mathrm{W}$ for the corresponding thermal resistance). And, both properties were significantly improved compared with those obtained in a previous study for the optimal self-bonded insulating board also made from sunflower cake $(15 \mathrm{~mJ}$ for energy-to-break, $12 \mathrm{~N}$ for breaking load, $272 \mathrm{kPa}$ for flexural strength at break, $99.5 \mathrm{~mW} / \mathrm{m} \mathrm{K}$ for thermal conductivity, and $0.161 \mathrm{~m}^{2}$ $\mathrm{K} / \mathrm{W}$ for the corresponding thermal resistance) (Evon et al., 2014). Fitted on walls and ceilings, this optimal fiberboard (board S3) could be used for the thermal insulation of buildings, even if it revealed much more important thermal conductivity compared with conventional materials like expanded polystyrene $(37.4 \mathrm{~mW} / \mathrm{m} \mathrm{K})$, rock wool $(35.6 \mathrm{~mW} / \mathrm{m}$ $\mathrm{K}$ ), or glass wool (35.4 mW/m K) (Vandenbossche et al., 2012). Measurements made on the bulk cake indicated that it was an even better insulation material (only $62.0 \mathrm{~mW} / \mathrm{m} \mathrm{K}$ for thermal conductivity at $25{ }^{\circ} \mathrm{C}$, and $0.839 \mathrm{~m}^{2} \mathrm{~K} / \mathrm{W}$ for thermal resistance) (Table 4), which was certainly due to its very low bulk density $\left(215 \mathrm{~kg} / \mathrm{m}^{3}\right)$ and to its porous structure. It also would be suitable for the thermal insulation of houses as loose fill in attic spaces. 


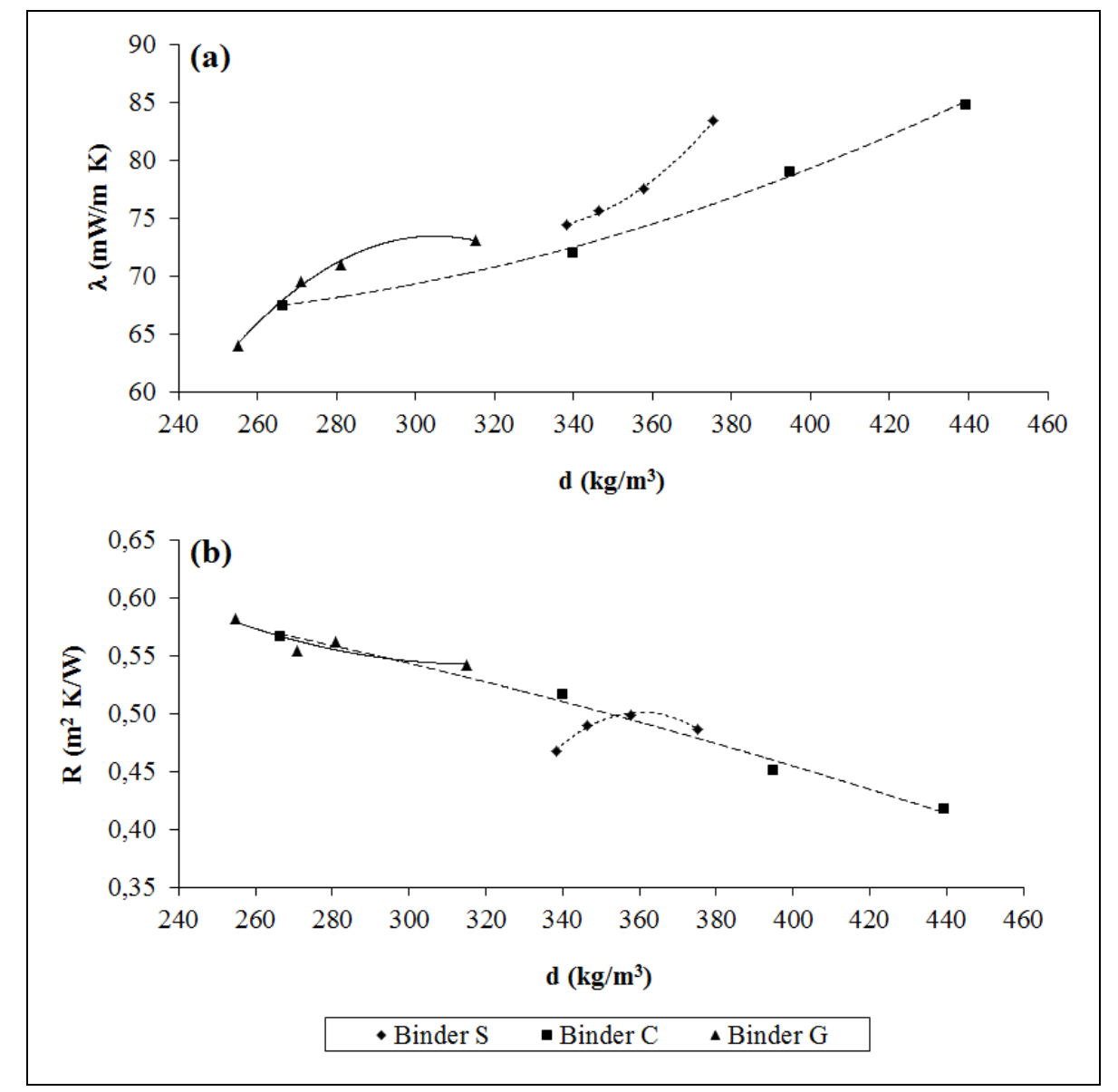

Figure 4. Thermal conductivity (a) and thermal resistance (b) at $25^{\circ} \mathrm{C}$ of the twelve fiberboards manufactured by compression molding, as a function of their density.

To conclude, the optimal fiberboard, i.e. board S3, was a natural composite material like all the others, and the external binders used contributed to obtain panels with good cohesion and at the same time with lower density compared with a previous study (Evon et al., 2014), thus contributing to better heat insulation properties. Moreover, the reinforcing fibers inside these panels originated essentially from sunflower stalks and heads, and these fibers are not now commercially available, the sunflower harvest concerning only the seeds. However, their promising ability for both reinforcement of composite materials and thermal insulation could, in the future, justify their harvest in the field at the same time as the seeds. Which in turn could generate an additional source of income for farmers.

\section{Conclusion}

New thermal insulation fiberboards were manufactured from a cake generated during the biorefinery of sunflower whole plant using a twin-screw extruder. All fiberboards were cohesive mixtures of an external natural binder and fibers from the cake. The binder contributed to ensure the board cohesion, and entanglement of fibers also acted as reinforcement. The molding conditions, i.e. binder type and binder content, had an important influence on board density and on mechanical and heat insulation properties. The density of the insulation materials varied from 255 to $439 \mathrm{~kg} / \mathrm{m}^{3}$. The heat insulation properties 
improved with decreasing density. The board containing $20 \%$ starch-based binder $\left(358 \mathrm{~kg} / \mathrm{m}^{3}\right.$ density) was a good compromise between mechanical and heat insulation properties. Thus, positioned on walls and ceilings, it could be used as thermal insulation in the construction industry. The heat insulation capacity of the bulk cake was even better. It also would be suitable for the thermal insulation of houses when used as loose fill in attic spaces.

\section{References}

Alavez-Ramirez, R., Chiñas-Castillo, F., Morales-Dominguez, V. J., \& Ortiz-Guzman, M. (2012). Thermal conductivity of coconut fibre filled ferrocement sandwich panels. Construction and Building Materials, 37, 425-431. http://dx.doi.org/10.1016/j.conbuildmat.2012.07.053

Ardente, F., Beccali, M., Cellura, M., \& Mistretta, M. (2008). Building energy performance: A LCA case study of kenaf-fibres insulation board. Energy and Buildings, 40, 1-10. http://dx.doi.org/10.1016/j.enbuild.2006.12.009

Benfratello, S., Capitano, C., Peri, G., Rizzo, G., Scaccianoce, G., \& Sorrentino, G. (2013). Thermal and structural properties of a hemp-lime biocomposite. Construction and Building Materials, 48, 745-754. http://dx.doi.org/10.1016/j.conbuildmat.2013.07.096

Chikhi, M., Agoudjil, B., Boudenne, A., \& Gherabli, A. (2013). Experimental investigation of new biocomposite with low cost for thermal insulation. Energy and Buildings, 66, 267-273. http://dx.doi.org/10.1016/j.enbuild.2013.07.019

Evon, P., Vandenbossche, V., Pontalier, P. Y., \& Rigal, L. (2010a). The twin-screw extrusion technology, an original and powerful solution for the biorefinery of sunflower whole plant. Oléagineux Corps gras Lipides, 17, 404-417. http://dx.doi.org/10.1051/ocl.2010.0339

Evon, P., Vandenbossche, V., Pontalier, P. Y., \& Rigal, L. (2010b). Thermo-mechanical behaviour of the raffinate resulting from the aqueous extraction of sunflower whole plant in twin-screw extruder: manufacturing of biodegradable agromaterials by thermopressing. Advanced Materials Research, 112, 63-72.

http://dx.doi.org/10.4028/www.scientific.net/AMR.112.63

Evon, P., Rigal, L., Pontalier, P. Y., \& Vandenbossche, V. (2012a). Procédé de fabricationd'un matériau solide à partir d'une plante oléagineuse et matériau solide obtenu. French Patent FR 2967689.

Evon, P., Vandenbossche, V., \& Rigal, L. (2012b). Thermo-pressing of cake meal from sunflower whole plant, one only operation for two actions: expression of residual oil and molding of biodegradable agromaterials. In: Proceedings of the 18th International Sunflower Conference. Mar del Plata, Argentina; pp. 937-942.

Evon, P., Vandenbossche, V., \& Rigal, L. (2012c). Manufacturing of renewable and biodegradable fiberboards from cake generated during biorefinery of sunflower whole plant in twin-screw extruder: Influence of thermo-pressing conditions. Polymer Degradation and Stability, 97, 1940-1947. http://dx.doi.org/10.1016/j.polymdegradstab.2012.01.025

Evon, P., Vandenbossche, V., Pontalier, P. Y., \& Rigal, L. (2014). New thermal insulation fiberboards from cake generated during biorefinery of sunflower whole plant in a twin-screw extruder. Industrial Crops and Products, 52, 354-362.

http://dx.doi.org/10.1016/j.indcrop.2013.10.049 
Evon, P., Vinet, J., Labonne, L., \& Rigal, L. (2015). Influence of thermo-pressing conditions on the mechanical properties of biodegradable fiberboards made from a deoiled sunflower cake. Industrial Crops and Products, 65, 117-126.

http://dx.doi.org/10.1016/j.indcrop.2014.11.036

Khedari, J., Charoenvai, S., \& Hirunlabh, J. (2003). New insulating particleboards from durian peel and coconut coir. Building and Environment, 38, 435-441.

http://dx.doi.org/10.1016/S0360-1323(02)00030-6

Khedari, J., Nankongnab, N., Hirunlabh, J., \& Teekasap, S. (2004). New low-cost insulation particleboards from mixture of durian peel and coconut coir. Building and Environment, 39, 59-65. http://dx.doi.org/10.1016/j.buildenv.2003.08.001

Korjenic, A., Petránek, V., Zach, J., \& Hroudová, J. (2011). Development and performance evaluation of natural thermal-insulation materials composed of renewable resources. Energy and Buildings, 43, 2518-2523. http://dx.doi.org/10.1016/j.enbuild.2011.06.012

Kymäläinen, H. R., \& Sjöberg, A. M. (2008). Flax and hemp fibres as raw materials for thermal insulations. Building and Environment, 43, 1261-1269.

http://dx.doi.org/10.1016/j.buildenv.2007.03.006

Lertsutthiwong, P., Khunthon, S., Siralertmukul, K., Noomun, K., \& Chandrkrachang, S. (2008). New insulating particleboards prepared from mixture of solid wastes from tissue paper manufacturing and corn peel. Bioresource Technology, 99, 4841-4845.

http://dx.doi.org/10.1016/j.biortech.2007.09.051

Mati-Baouche, N., De Baynast, H., Lebert, A., Sun, S., Lopez-Mingo, C. J. S., Leclaire, P., \& Michaud, P. (2014). Mechanical, thermal and acoustical characterizations of an insulating bio-based composite made from sunflower stalks particles and chitosan. Industrial Crops and Products, 58, 244-250. http://dx.doi.org/10.1016/j.indcrop.2014.04.022

Nicolajsen A. (2005). Thermal transmittance of a cellulose loose-fill insulation material. Building and Environment, 40, 907-914. http://dx.doi.org/10.1016/j.buildenv.2004.08.025

Paiva, A., Pereira, S., Sá, A., Cruz, D., Varum, H., \& Pinto, J. (2012). A contribution to the thermal insulation performance characterization of corn cob particleboards. Energy and Buildings, 45, 274-279. http://dx.doi.org/10.1016/j.enbuild.2011.11.019

Panyakaew, S., \& Fotios, S. (2011). New thermal insulation boards made from coconut husk and bagasse. Energy and Buildings, 43, 1732-1739.

http://dx.doi.org/10.1016/j.enbuild.2011.03.015

Pinto, J., Paiva, A., Varum, H., Costa, A., Cruz, D., Pereira, S., Fernandes, L., Tavares, P., \& Agarwal, J. (2011). Corn's cob as a potential ecological thermal insulation material. Energy and Buildings, 43, 1985-1990. http://dx.doi.org/10.1016/j.enbuild.2011.04.004

Saiah, R., Perrin, B., \& Rigal, L. (2010). Improvement of thermal properties of fired clays by introduction of vegetable matter. Journal of Building Physics, 34, 124-142.

http://dx.doi.org/10.1177/1744259109360059

Sampathrajan, A., Vijayaraghavan, N. C., \& Swaminathan, K. R. (1992). Mechanical and thermal properties of particle boards made from farm residues. Bioresource Technology, 40, 249-251. http://dx.doi.org/10.1016/0960-8524(92)90151-M 


\section{Macrothink}

Van Soest, P. J., \& Wine, R. H. (1967). Use of detergents in the analysis of fibrious feeds. IV. Determination of plant cell wall constituents. Journal of AOAC International, 50, 50-55.

Van Soest, P. J., \& Wine, R. H. (1968). Determination of lignin and cellulose in acid detergent fiber with permanganate. Journal of AOAC International, 51, 780-784.

Vandenbossche, V., Rigal, L., Saiah, R., \& Perrin, B. (2012). New agro-materials with thermal insulation properties. In: Proceedings of the 18th International Sunflower Conference. Mar del Plata, Argentina; pp. 949-954.

Zhou, X. Y., Zheng, F., Li, H. G., \& Lu, C. L. (2010). An environment-friendly thermal insulation material from cotton stalk fibers. Energy and Buildings, 42, 1070-1074.

http://dx.doi.org/10.1016/j.enbuild.2010.01.020

\section{Copyright Disclaimer}

Copyright for this article is retained by the author(s), with first publication rights granted to the journal.

This is an open-access article distributed under the terms and conditions of the Creative Commons Attribution license (http://creativecommons.org/licenses/by/3.0/). 